\title{
The inflammatory process in polymyositis: monoclonal antibody analysis of muscle and peripheral blood immunoregulatory lymphocytes
}

\author{
WILHELMINA M H BEHAN,* P O BEHAN, $\dagger$ W F DURWARD, $\ddagger$ A McQUEEN \\ From the Departments of Pathology, ${ }^{*}$ Neurology, $\dagger \ddagger$ and Dermatology, $\S$ of Glasgow University, UK
}

\begin{abstract}
SUMMARY An analysis was made of the lymphocyte subpopulations in the muscle lesions and the peripheral blood of 25 patients with inflammatory myopathy, in the acute or chronic phase of the disease. Percentages of activated $T$ lymphocytes $(65 \% \pm 3.4)$, both helper and suppressor/cytotoxic, macrophages $(25 \% \pm 3.2)$ and $B$ cells $(11 \% \pm 0.9)$ in the tissues were similar at all stages of the illness; T cells were, however, more common in acute polymyositis than in acute dermatomyositis, where B cells were significantly increased. A loss of circulating OKT8-positive lymphocytes in the peripheral blood was demonstrated, supporting other evidence of disturbed immunoregulation. It was concluded that the attack on muscle fibres is mediated by $\mathrm{T}$ cells, macrophages, and $\mathrm{B}$ cells, with the first two playing the major roles.
\end{abstract}

The nature and range of immunological abnormalities in polymyositis and dermatomyositis, together with the typical muscle biopsy findings, have long suggested that a disturbance in immune homeostasis plays a significant pathogenic role in these inflammatory myopathies. ${ }^{1} \mathrm{~A}$ loss of the regulatory suppressor $T$ lymphocytes from the peripheral blood in acute cases, ${ }^{2}$ similar to that found in multiple sclerosis, ${ }^{3}$ supports this view, while the analysis of the cellular infiltrates in affected muscle has started to reveal the characteristics of the immunological cells concerned. ${ }^{4-9}$ Some workers have stressed the involvement of helper T cells, ${ }^{45}$ but others have concluded that cytotoxic-suppressor lymphocytes and macrophages are of most importance,$^{6-9}$ with perhaps a local humoral effect also present in dermatomyositis. ${ }^{6}$ The problem is compounded by finding the same inflammatory cells, in similar proportions, in inherited muscle diseases such as Duchenne dystrophy, and in non-inflammatory myopathies. ${ }^{68}$ In addition, the number of cases studied is still small, with very few patients from the different clinical subgroups or stages of the disease.

We report here a group of 25 cases studied at the

Address for reprint requests: Dr Peter O Behan, Department of Neurology, Institute of Neurological Sciences, Southern General Hospital, 1345 Govan Road, Glasgow G51 4TF, UK.

Received 23 December 1986 and in revised form 6 May 1987. Accepted 8 May 1987 onset or during the chronic, active phase of their illness. Monoclonal antibody analyses of the lymphocyte subsets in the muscle infiltrates are correlated with those in the peripheral blood. In a further five patients who had recovered from polymyositis, the blood findings alone are given.

\section{Materials and methods}

\section{Patients}

The 30 patients consisted of six males and 24 females (table 1). The diagnosis was based on clinical, laboratory, electrophysiological and pathological features, according to standard criteria. ${ }^{10}$ The patients were classified into those with acute disease (10 cases), in whom the disorder had been present for from 6 weeks to 3 months and those with chronic disorder ( 15 cases) ill for from 3 months up to 11 years. Five cases had recovered, from 2 to 12 years previously. Patients with acute disease were not on any medication when they were studied. In the chronic group, seven cases were taking prednisolone $5-10 \mathrm{mg}$ on alternate days. The patients were also allocated into the usual clinical subgroups, ${ }^{10}$ that is, Group I, pure polymyositis (13 cases); Group II, pure dermatomyositis (11 cases); Group III, polymyositis or dermatomyositis with neoplasia (two cases); Group IV, juvenile polymyositis or dermatomyositis (two cases); Group V, polymyositis or dermatomyositis associated with a connective tissue disease (two cases). In the last group, one patient had associated rheumatoid arthritis and the other, scleroderma.

Histochemical analysis of cellular infiltrates in muscle Biopsy specimens were from vastus lateralis muscle. Twenty- 
Table 1 Clinical details of 30 cases of polymyositis

\begin{tabular}{|c|c|c|c|c|}
\hline Clinical subgroup & Disease phase & No and sex of patients & Ages (yr) & Serum creatine kinase Iu/l \\
\hline Pure PM & $\begin{array}{l}\text { Acute } \\
\text { Chronic } \\
\text { Recovered }\end{array}$ & $\begin{array}{l}4 \mathrm{~F} \\
5 \mathrm{~F}, 3 \mathrm{M} \\
1 \mathrm{M}\end{array}$ & $\begin{array}{l}22-56(43)^{*} \\
31-59(46) \\
52\end{array}$ & $\begin{array}{l}200-17,000(5125)^{*} \\
34-760(272) \\
30\end{array}$ \\
\hline Pure DM & $\begin{array}{l}\text { Acute } \\
\text { Chronic } \\
\text { Recovered }\end{array}$ & $\begin{array}{l}3 \mathrm{~F}, 3 \mathrm{M} \\
2 \mathrm{~F}, 1 \mathrm{M} \\
2 \mathrm{~F}\end{array}$ & $\begin{array}{l}45-73(59) \\
36-52(43) \\
22,46\end{array}$ & $\begin{array}{c}200-3,500(1302) \\
60-465(202) \\
40,37\end{array}$ \\
\hline PM/DM with neoplasia & $\begin{array}{l}\text { Chronic } \\
\text { Recovered }\end{array}$ & $1 \mathrm{~F}$ & $\begin{array}{l}54 \\
68\end{array}$ & 375 \\
\hline Juvenile PM/DM & $\begin{array}{l}\text { Chronic } \\
\text { Recovered }\end{array}$ & $1 \mathrm{~F}$ & $\begin{array}{l}17 \\
14\end{array}$ & $\begin{array}{r}800 \\
40\end{array}$ \\
\hline PM/DM with a connective tissue disorder & Chronic & $1 \mathrm{~F}, 1 \mathrm{M}$ & 33,56 & 105,520 \\
\hline
\end{tabular}

*mean is shown in brackets.

PM: polymyositis, DM: dermatomyositis.

five from the acute and chronic cases were examined by a direct immunoperoxidase method, as previously described. ${ }^{11}$ The five patients who had recovered were not biopsied. The specimens were stored in liquid nitrogen until use and then sections were cut at $5 \mu \mathrm{m}$, placed two on a slide, wrapped in aluminium foil and left at room temperature overnight. If they were not to be stained within 24 hours, they were stored in a desiccator. The monoclonal antibodies used are shown in table 2 . A slightly different set of antibodies were used for tissues compared with blood because we found the Ortho antibodies did not stain the tissue cells satisfactorily although they were very effective in labelling peripheral blood subsets. Polyclonal antibodies, anti IgG, anti IgA and anti IgM (Dakopatts, rabbit antihuman) were also used (see below). For the primary layer, the monoclonal antibodies were diluted to $1 / 40$ for use and the polyclonal, to $1 / 400$. For the secondary layer, horseradish peroxidaselabelled antibody at $1 / 50$ dilution (rabbit antimouse $\mathbf{I g G}$, HRP, Dakopatts) was employed. Two negative controls were incorporated into the staining schedule: one to control for non-specific peroxidase staining and one for non-specific adherence of the second antibody layer. After treatment with diaminobenzene the slides were counterstained.with haematoxylin. They were then washed, cleared through alcohols and xylene in the usual manner and mounted in DPX.
Sections of normal tonsil were used as controls for the monoclonal antibodies.

A total of 14 slides was examined from each biopsy. They were always cut and stained in the same sequence, that is, haematoxylin-eosin alone, then anti-leucocyte antibody, Leu 4, Leu 3a, Leu 2a, OKM I, Leu 12, OKIa 1, IgG, IgA, IgM and Leu 7, followed by the two controls.

Each section was assessed by two independent observers, unaware of the patient's classification. The sections were examined in the same sequence as in the staining schedule, starting with the haematoxylin and eosin slide, so that the sites of cellular infiltration could be defined as perimysial, perivascular and endomysial. The anti-leucocyte antibody preparation ensured that no sarcolemmal or endothelial cells were included in the counts. Before the individual cell counts were done, an estimate of the density of the cell infiltrates in the perimysial, perivascular and endomysial areas was carried out, graded as previously described ${ }^{6}$ according to the number of positive cells: grade 0 : no positive cells; 1 : from 1 to 25 cells; 2 : from $26-50$ cells and 3 : more than 50 cells.

Following this, for each specimen three cellular aggregates were counted, at each of the three sites: the results in the patient's biopsy represented approximately 100-700 labelled cells. A positive reaction consisted of a well-defined rim to the cell, or in the case of the OKM-1 antibody (macrophage-

Table 2 Monoclonal antibodies used to localise surface antigens

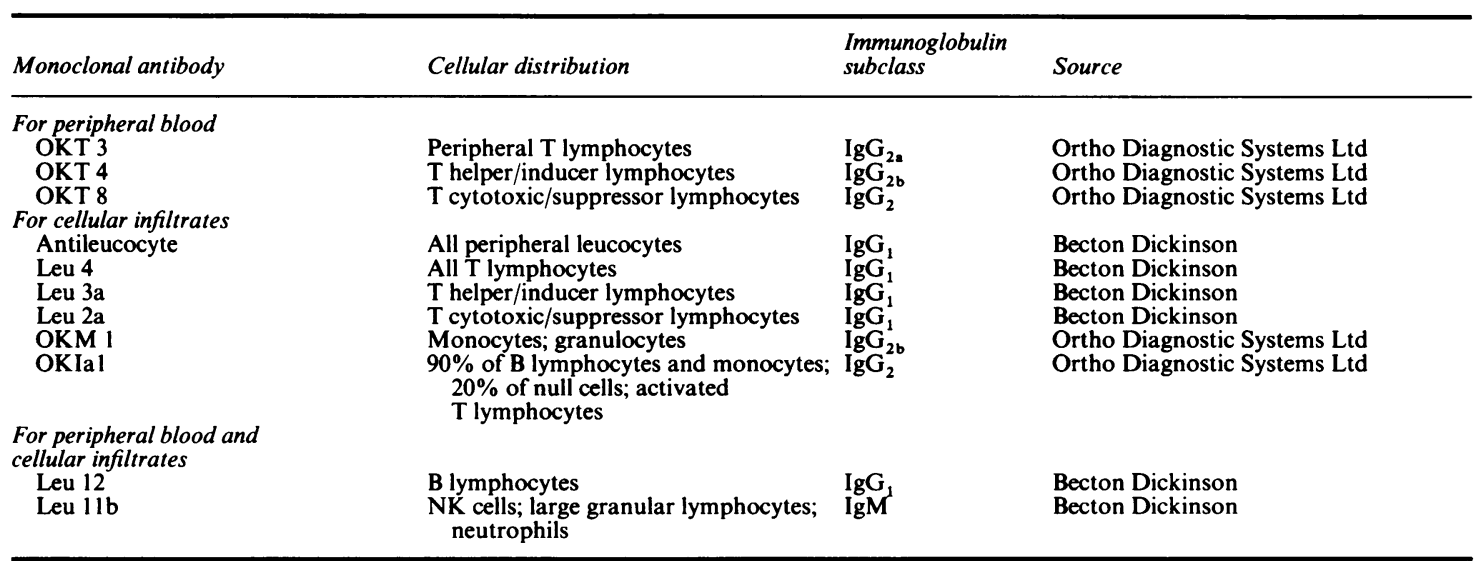


marker) also included a cytoplasmic brown colouration. In order to identify the $\mathrm{T}$ lymphocytes which were activated, the OKIal antibody was used and the number of activated $T$ cells was then calculated according to the formula:

$\mathrm{OKIa}^{+}{ }^{+} \mathrm{T}$ cells $=$ all $\mathrm{OKIal}{ }^{+}$cells $-[\mathrm{OKM}-1$ (macrophages) + Leu 12(B) cells]

Thus macrophages and B cells also labelled with the OKIal antibody could be discounted.

Finally, in five acute cases [four of polymyositis and one of dermatomyositis] the cellular clusters adjacent to histologically normal and necrotic fibres were counted separately.

\section{Peripheral blood lymphocytes subset analysis}

A $25 \mathrm{ml}$ sample of venous blood was taken from the patient between 9 and 11 am and placed in a sterile heparinised container. $10 \mathrm{ml}$ was used for the subset analysis and $15 \mathrm{ml}$ for a functional suppressor cell assay (see below). Total and differential white blood counts were carried out on the same samples. Mononuclear cells were obtained from the peripheral blood samples using Ficoll-Hypaque density centrifugation (Pharmacia Ltd, Milton Keynes) and then labelled with monoclonal antibodies as described. ${ }^{12}$ The antibodies used are shown in table 2 . The labelled cells were visualised using fluorescein-conjugated $\mathrm{F}(\mathrm{ab})_{2}$ anti-mouse IgG (New England Nuclear, Boston, Massachusetts) and counted in the fluorescence-activated cell sorter (FACS-IV model, Becton Dickinson, Mountain View, California). Before counting, the cells were fixed by resuspending them in $1.0 \mathrm{ml}$ of $0.85 \%$ saline containing $1 \%$ paraformaldehyde and stored in the dark at $4^{\circ} \mathrm{C}$. The FACS results were obtained through the kindness of Dr HS Micklem, in the Department of Zoology, Edinburgh University, who had previously introduced two technical modifications: ${ }^{1314}$ logarithmic amplification of the fluorescent signal, to give a clear distinction between labelled and unlabelled cells; and $90^{\circ}$ scatter to eliminate contaminating monocytes. A minimum of 10,000 lymphocytes was counted and the data analysed using Student's $t$ test.

\section{Functional suppressor cell assay}

Since suppressor and cytotoxic lymphocytes are each labelled with the same OKT8 marker, it is essential in peripheral blood studies to carry out an assay for functional suppressor cell activity at the same time, to confirm any loss of these cells. The assay is performed in two stages: first, the patient's lymphocytes are stimulated in vitro by Concanavalin A (Con A) to release suppressor factors into the supernatant. In the next stage, the effect of the suppressorfactor-containing supernatant (SFCS) on phytohaemagglutinin (PHA)-induced uptake of tritiated thymidine by peripheral blood lymphocytes is measured. In these studies, the latter lymphocytes were always from the same control subject (WMB). The first stage of the test was according to the method of Greene et $a^{15}$ while in the second stage, a whole blood technique was used for measuring the inhibition of blastogenesis. ${ }^{16}$ Stimulation indices (SI) for PHA-stimulated cells alone and for PHA-stimulated cells exposed to SFCS, were obtained and the suppressor function is calculated as a percentage from the following formula:

$$
\% \text { suppression }=1-\frac{\text { SI with PHA }+ \text { SFCS }}{\text { SI with PHA alone }} \times 100
$$

\section{Control populations}

Peripheral blood samples were taken from two other groups of patients: first, 35 patients with other neuromuscular diseases, that is, Guillain-Barre syndrome (two), familial brachial neuralgia (five), alcoholic myopathy (two), hereditary neurological amyloidosis (two), motor neuron disease (seven), migraine (seven), lumbar disc problems (six), myotonic dystrophy (four) and secondly, 35 healthy age and sexmatched volunteers.

\section{Results}

\section{Cellular infiltrates}

All types of immunocytes including $T$ cells of both helper and suppressor/cytotoxic phenotype, macrophages and B cells, were present in the perivascular, perimysial and endomysial areas. Very rare Leu 11b-positive (K/NK lymphocytes), never amounting to more than $1-2 \%$, were also identified. Plasma cells were even more uncommon: IgG-bearing cells formed less than $1 \%$ of labelled cells and IgA and IgMbearing cells were not detected at all. The density of the cellular infiltrates at the three different sites varied, increasing from the perivascular region $(25 \pm 6 \%)$ to the perimysial $(30 \pm 5 \%)$ to the endomysial areas (50-9\%), in both acute and chronic cases, and in the different subgroups but the percentage of each cell type was unchanged.

In table 3 the endomysial scores are presented. It can be seen that $T$ lymphocytes were invariably most common, with the percentage ranging from 49 to $79 \%$ (mean $65 \pm 3.4 \%$ ). In patients with polymyositis, the percentages of $\mathrm{T}$ cells were, for the acute cases, $57 \pm 8.2 \%$ and for the chronic $61 \pm 9.0 \%$; while patients with dermatomyositis had values of 70 $\pm 8.8 \%$ and $66 \pm 6.1 \%$ respectively. As regards disease phase, no correlation between this and the $T$ cell percentages could be established: patients with polymyositis had a lower percentage of infiltrating $T$ cells in the acute lesions compared to the chronic but the reverse was seen in the cases of dermatomyositis. In all the lesions studied, about one-half of the $T$ cells were activated, expressing the Ia antigen. There were only four patients from the other clinical subgroups. Their results were similar with $T$ cell percentages of from $62-74 \%$.

With regard to the helper and suppressor/cytotoxic subsets (table 3) it was found that the percentages of the former $(44 \pm 2.5 \%)$ were usually twice the values of the latter $(21 \pm 2 \cdot 0 \%)$. For the helper cells, patients with acute and chronic polymyositis had very similar percentages: $39 \pm 4 \cdot 1 \%$ and $44 \pm 7 \cdot 1 \%$ while for acute and chronic dermatomyositis, the figures were $47 \pm 6.8 \%$ and $40 \pm 3.0 \%$. These values are not significantly different, nor were those in the patients from the other clinical subgroups. Suppressor/ cytotoxic lymphocyte percentages in cases of acute 
Table 3 Mononuclear cell subsets in muscle infiltrates of 25 cases with comparison of the helper/suppressor and cytotoxic ratios with that in peripheral blood

\begin{tabular}{|c|c|c|c|c|c|c|c|c|}
\hline \multirow[b]{2}{*}{ Clinical subgroup } & \multirow[b]{2}{*}{ Disease phase } & \multicolumn{5}{|c|}{ Muscle biopsy findings (\%) } & \multicolumn{2}{|c|}{$\begin{array}{l}\text { Helper/suppressor- } \\
\text { cytotoxic ratio }\end{array}$} \\
\hline & & Total T cells & Thelper & $\begin{array}{l}\text { T suppressor/ } \\
\text { cytotoxic }\end{array}$ & Macrophages & B cells & Muscle & Blood \\
\hline $\begin{array}{l}\text { Pure PM } \\
\text { Pure DM } \\
\text { PM + neoplasia } \\
\text { Juvenile DM }\end{array}$ & $\begin{array}{l}\text { Acute (4) } \\
\text { Chronic (8) } \\
\text { Acute (6) } \\
\text { Chronic (3) } \\
\text { Chronic (1) } \\
\text { Chronic (1) }\end{array}$ & $\begin{array}{l}57 \pm 8 \cdot 2^{*} \\
61 \pm 9 \cdot 0 \\
70 \pm 8 \cdot 8 \\
66 \pm 6 \cdot 1 \\
74 \\
62\end{array}$ & $\begin{array}{l}39 \pm 4 \cdot 1 \\
44 \pm 7 \cdot 1 \\
47 \pm 6 \cdot 8 \\
40 \pm 3 \cdot 0 \\
51 \\
53\end{array}$ & $\begin{array}{l}18 \pm 4 \cdot 2 \\
18 \pm 4 \cdot 1 \\
20 \pm 4 \cdot 5 \\
27 \pm 4 \cdot 8 \\
26 \\
10\end{array}$ & $\begin{array}{l}36 \pm 9 \cdot 4 \\
29 \pm 6 \cdot 6 \\
21 \pm 8 \cdot 1 \\
24 \pm 6 \cdot 6 \\
15 \\
39\end{array}$ & $\begin{array}{l}7 \pm 1 \cdot 0 \\
10 \pm 2 \cdot 1 \\
12 \pm 2 \cdot 1 \\
12 \pm 2 \cdot 5 \\
15 \\
6\end{array}$ & $\begin{array}{l}2.3 \pm 0.4 \\
2.9 \pm 0.6 \\
2.7 \pm 0.5 \\
1.7 \pm 0.5 \\
2.0 \\
5.3\end{array}$ & $\begin{array}{l}4 \cdot 7 \pm 1 \cdot 4 \\
4 \cdot 5 \pm 0 \cdot 8 \\
5 \cdot 1 \pm 1 \cdot 8 \\
6 \cdot 3 \pm 2 \cdot 1 \\
2 \cdot 1 \\
2 \cdot 0\end{array}$ \\
\hline $\begin{array}{l}\text { tissue disorder } \\
\text { Total }\end{array}$ & $\begin{array}{l}\text { Chronic (2) } \\
\mathrm{n}=25\end{array}$ & $\begin{array}{l}73,70 \\
65 \pm 3 \cdot 4\end{array}$ & $\begin{array}{l}43,44 \\
44 \pm 2 \cdot 5\end{array}$ & $\begin{array}{l}31,28 \\
21 \pm 2 \cdot 0\end{array}$ & $\begin{array}{l}15,18 \\
25 \pm 3 \cdot 2\end{array}$ & $\begin{array}{l}10,11 \\
11 \pm 0.9\end{array}$ & $\begin{array}{l}1 \cdot 4,1 \cdot 6 \\
2 \cdot 5 \pm 0 \cdot 3\end{array}$ & $\begin{array}{l}4 \cdot 5,4 \cdot 2 \\
4 \cdot 8 \pm 0 \cdot 7\end{array}$ \\
\hline
\end{tabular}

*mean \pm SD.

and chronic polymyositis were almost identical (18 \pm $4 \cdot 1 \%$ and $18+4 \cdot 2 \%$ ) while in the acute and chronic dermatomyositis, the values were $20 \pm 4.5 \%$ and 27 $\pm 4.8 \%$ respectively, revealing a significant $(\mathrm{p}=$ 0.01 ) decrease in patients with chronic polymyositis versus those with chronic dermatomyositis.

The figures for the four patients in the other subgroups varied widely, from only $10 \%$ of suppressor/cytotoxic cells in the girl with chronic juvenile dermatomyositis to $26 \%$ in the patient with an associated neoplasia.

Macrophages formed from 15 to $45 \%$ (25 $\pm 3 \cdot 2 \%$ ) of the inflammatory infiltrate and were significantly more common $(p=0.03)$ in the lesions of patients with acute polymyositis compared to acute dermatomyositis. These cells were least common in the lesions of cases associated with neoplasia, rheumatoid arthritis and scleroderma.

B cells formed a minority of the cellular aggregates in all cases, never amounting to more than $15 \%$ (mean $11 \pm 0.9 \%$ ). They were, however, significantly decreased in acute polymyositis compared with acute dermatomyositis and chronic polymyositis.

The helper and suppressor/cytotoxic ratios in muscle and blood are compared in the last two columns of table 3. If the increased blood ratio is associated with a disproportionate migration of suppressor/ cytotoxic, rather than helper, cells into the damaged muscle, then the ratio in muscle should be less than that in the blood. This is in fact shown for all groups, with a single exception, the case of chronic juvenile DM.

Table 4 shows separate analyses of the focal cellular clusters associated either with individual necrotic fibres or adherent to apparently healthy fibres, in five cases (four of acute polymyositis and one of acute dermatomyositis). Two clusters in each category were analysed for each biopsy. These aggregates amounted to no more than 25 cells and, indeed, those adjacent to uninvolved fibres, usually consisted of less, that is, approximately 10 . It can be seen that $T$ cells, macrophages and $B$ cells are present in both infiltrates, but $\mathrm{T}$ cells are in the majority near uninvolved fibres while macrophages predominate in the aggregates surrounding necrotic myocytes. Near uninvolved fibres, $T$ suppressor/cytotoxic cells are more common than helper, while the reverse is true for necrotic fibres. Rare K cells were found near unaffected fibres but were not associated with necrotic ones.

The peripheral blood findings are shown in detail in table 5. Significant, severe decreases in T8-positive lymphocyte percentages were identified in patients with acute and chronic polymyositis, with values of $15 \pm 3 \%$ and $16 \pm 2 \%$, compared to the normal value of $22 \pm 1 \%$. The T4/T8 ratios were also significantly increased in the same group, $6.0 \pm 1.4$ and $5 \cdot 0 \pm 1 \cdot 2$, against a normal of $2 \cdot 2 \pm 0 \cdot 1$. In contrast to the loss of $T$ cells, $B$ cell percentages were increased in both these groups, reaching significant increases in patients with acute disease. The $\mathrm{K}$ cell percentages were unchanged. In the patients who had recovered, the $T$ lymphocyte subset percentages were all normal, as was the T4/T8 ratio. The B cell percentages, however, remained slightly but significantly increased at $19 \pm 2 \%$, compared with $11 \pm 1 \%$.

Table 4 Inflammatory cell aggregates at surface of necrotic and unaffected fibres in five cases

\begin{tabular}{lll}
\hline Cells & Unaffected fibres & Necrotic fibres \\
\hline T lymphocytes (Leu 4) & $52 \pm 10^{*}$ & $40 \pm 9$ \\
T helper (Leu 3a) & $43 \pm 6$ & $50 \pm 8$ \\
T suppressor/cytotoxic & $60 \pm 7$ & $44 \pm 9$ \\
$\quad$ (Leu 2a) & $30 \pm 6$ & $45 \pm 4$ \\
Macrophages (OKM 1) & $5 \pm 4$ & $6 \pm 4$ \\
B cells (Leu 12) & $1-2$ & 0 \\
K/NK cells (Leu 11b) & &
\end{tabular}

*\% \pm SD. 
Table 5 Analysis of peripheral blood lymphocyte subsets in 30 patients with polymyositis

\begin{tabular}{|c|c|c|c|c|c|c|}
\hline \multirow[b]{2}{*}{ Patient group } & \multicolumn{6}{|c|}{ Per cent reactivity with monoclonal antibodies } \\
\hline & $\begin{array}{l}O K T 3^{+} \\
T t\end{array}$ & $\begin{array}{l}\text { OKT4 } \\
T h\end{array}$ & $\begin{array}{l}O K T 8^{+} \\
T s / c\end{array}$ & $\operatorname{Leu}_{B} 12^{+}$ & $\begin{array}{l}\text { Leu } 11 b^{+} \\
N K\end{array}$ & $T 4 / T 8$ ratio \\
\hline $\begin{array}{l}\text { Acute }(n=10) \\
P= \\
\text { Chronic active PM }(n=15) \\
P= \\
\text { Recovered from } P M(n=5) \\
P= \\
\text { Other neurological disease }(n=35) \\
P= \\
\text { Normal healthy controls }(n=35)\end{array}$ & $\begin{array}{l}63 \pm 5^{*} \\
<0 \cdot 05 \\
72 \pm 3 \\
\mathrm{NS} \\
71 \pm 4 \\
\mathrm{NS} \\
70 \pm 3 \\
\mathrm{NS} \\
70 \pm 1\end{array}$ & $\begin{array}{l}54 \pm 5 \\
\mathrm{NS} \\
58 \pm 4 \\
<0 \cdot 02 \\
52 \pm 5 \\
\mathrm{NS} \\
47 \pm 2 \\
\mathrm{NS} \\
47 \pm 1\end{array}$ & $\begin{array}{l}15 \pm 3 \\
<0 \cdot 03 \\
16 \pm 2 \\
<0 \cdot 001 \\
24 \pm 1 \\
\mathrm{NS} \\
24 \pm 1 \\
\mathrm{NS} \\
22 \pm 1\end{array}$ & $\begin{array}{l}23 \pm 5 \\
<0 \cdot 01 \\
17 \pm 3 \\
\mathrm{NS} \\
19 \pm 2 \\
<0.01 \\
12 \pm 1 \\
\mathrm{NS} \\
11 \pm 1\end{array}$ & $\begin{array}{l}8 \pm 2 \\
\mathrm{NS} \\
8 \pm 2 \\
\mathrm{NS}^{ \pm} \pm 2 \\
9 \pm 2 \\
\mathrm{NS} \\
11 \pm 2 \\
\mathrm{NS} \\
10 \pm 1\end{array}$ & $\begin{array}{l}6 \cdot 0 \pm 1 \cdot 4 \\
<0 \cdot 01 \\
5 \cdot 0 \pm 1 \cdot 2 \\
<0 \cdot 01 \\
2 \cdot 1 \pm 0 \cdot 1 \\
\mathrm{NS} \\
2 \cdot 3 \pm 0 \cdot 2 \\
\mathrm{NS} \\
2 \cdot 2 \pm 0 \cdot 1\end{array}$ \\
\hline
\end{tabular}

* group results \pm standard error of the mean.

$\mathrm{p}$ values of significance are indicated; $\mathrm{NS}=$ not significant.

The functional suppressor cell assay results are given in table 6. For technical reasons, results were obtained only in eight acute cases and 14 of the chronic active cases, together with 20 each of the group with other neurological illnesses and the control population. It is apparent that the decreased percentage of T8-positive lymphocytes correlates with a significant decrease in nonspecific lymphocyte suppressor function in patients with acute and chronic disease, compared to normal controls and to those recovered from polymyositis.

\section{Discussion}

The nature of the immunological attack on the muscle fibre in polymyositis has become clearer over the last 5 years, owing to careful histochemical analyses of the cellular infiltrates. The first brief report indicated that activated $T$ cells predominated, both helper and cytotoxic/suppressor type. ${ }^{4517}$ Arahata and Engel, ${ }^{679}$ in their elegant work, confirmed recently, ${ }^{8}$ distinguished between cellular aggregates at perivascular, perimysial and endomysial sites in order to see if a particular population was concentrated around the damaged fibres. They also suggested technical modifications to make the counts more accurate and the latest workers have proposed a simpler, semiquantitative analysis. ${ }^{8}$

It has now been concluded that the muscle fibres are eliciting an immune response from activated $T$ cells whose effects are augmented by macrophages and B cells. Some workers reported significantly increased $B$ cells in dermatomyositis ${ }^{6}$ suggesting a local humoral response of importance. The number of cases studied, however, is still small: quantitative analyses have been carried out on less than 70 cases $^{468}$ now brought up to 93 , with the study reported here; it is therefore difficult to attempt any correlation with disease phase or clinical subgroup. Our 25 patients formed part of a large group whose clinical, pathological and immunological features have been very well characterised. ${ }^{1}$ We had 12 cases of polymyositis, nine of dermatomyositis, one each with the juvenile form of the disease and two, with the type associated with the mixed connective tissue disease syndrome. In addition, unlike other series, we divided the cases into those seen in the acute phase and not on treatment, and those wth chronic active illness.

Our study confirms that $\mathrm{T}$ lymphocytes form the majority of infiltrating cells $(65 \pm 3.4 \%)$ at all stages in this inflammatory myopathy, with macrophages being next common $(25 \pm 3 \cdot 2 \%)$ and B cells ( $11 \pm$ $0.9 \%$ ), least, the figures being similar to those of others. ${ }^{6}$ We also identified very rare Leu 11 b-positive (K/NK killer lymphocytes) in the tissues. We found significantly more $T$ cells in the lesions of patients with acute polymyositis compared to acute dermatomyositis, and the reverse for $B$ cells and macrophages. No other significant differences were identified between the different clinical subgroups or between the lesions seen in untreated patients with acute disease compared to those (treated) with chronic active illness. This supports the view that prednisolone produces a general, non-specific immunosuppressive effect.

Like Lemoine et al, ${ }^{8}$ we could not identify any differences between the proportions of cells present at perivascular, perimysial or endomysial sites. We did, however, find more helper than suppressor/cytotoxic cells in all the infiltrates, in contrast to their study, ${ }^{8}$

Table 6 Assay of peripheral blood lymphocyte supressor cell activity in patients with polymyositis

\begin{tabular}{ll}
\hline Group & Activity $(\% \pm S D)$ \\
\hline Acute polymyositis $(\mathrm{n}=8)$ & $42 \pm 15$ \\
Chronic, active polymyositis $(\mathrm{n}=14)$ & $35 \pm 12$ \\
Recovered from polymyositis $(\mathrm{n}=5)$ & $57 \pm 8 \cdot 2$ \\
Patients with other neurological diseases & $58 \pm 6 \cdot 2$ \\
$(\mathrm{n}=20)$ & $63 \pm 7 \cdot 5$ \\
Normal healthy controls $(\mathrm{n}=20)$ & \\
\hline
\end{tabular}


and that of Engel, ${ }^{6}$ but in agreement with others. ${ }^{45}$ The discrepancy may be explained by the fact that the cellular infiltrate evolves and changes during the disease process.

Which of the immunological cells present first attacks the muscle fibre is a primary consideration in identifying the nature of the immune attack and therefore the immunotherapy indicated. On immunoelectronmicroscopy, activated cytotoxic cells have been identified, sending long finger-like projections into apparently normal fibres and then entering the sarcoplasm; almost immediately thereafter, macrophages appeared. ${ }^{9}$ We analysed the focal cellular aggregates alongside or around histologically normal muscle fibres, compared with those beside necrotic fibres: certainly activated $\mathrm{T}$ lymphocytes were more common than macrophages adjacent to apparently normal fibres but the types were invariably present together. Similarly, both helper and suppressor/ cytotoxic lymphocytes were identified.

Thus, although Arahata and Engel ${ }^{9}$ suggest that T cells are the effectors of damage, there is no doubt that macrophages are an integral part of the immune process at all stages. In other autoimmune neurological disorders, the question as to whether $\mathrm{T}$ cells or macrophages are the agents in immune-mediated damage is still under consideration. ${ }^{18}$ Other questions also have to be answered: is it the same mechanism of damage in all clinical groups and, what changes are produced by treatment? Activation of cytotoxic $T$ cells is certainly a possibility; for instance, Appleyard et al $^{19}$ recently detected muscle fibre expression of Class I HLA antigens in cases of polymyositis and suggested this as an initiating factor. Others, however, dismiss this as a secondary phenomenon, related to the release of interferon by the inflammatory cells present. $^{20}$

Turning to the peripheral blood immunoregulatory findings, this report confirms our previous work ${ }^{321}$ and that of others ${ }^{1722}$ in showing that there is a loss of circulating OKT8-positive lymphocytes in cases of acute and chronic active polymyositis and that the abnormality disappears when the patients recover. The only dissenting report ${ }^{23}$ was based on seven cases which were studied by a method less accurate than ours. In our analysis, we took into account the effect of diurnal rhythm, ${ }^{24}$ patient age, ${ }^{25}$ stress $^{26}$ and immunosuppressive drugs. The results obtained were not due to therapy since patients with acute disease, eight of those with chronic illness, and the five who had recovered, were on no drugs. Total lymphocyte counts were above $800 \mathrm{~mm}^{3}$ in all cases and none had a lymphocytosis. With regard to the seven patients on alternate day prednisolone, the seven matched control patients also on this drug had normal subset percentages. The method used was accurate and reproducible, carried out using the FACS IV cell sorter with the help of Dr HS Micklem, who has introduced the most widely used improvements to this technique. ${ }^{1314}$ Our findings indicate, therefore, that there is a disturbance in immunoregulatory cells in this disorder: this evidence is supported by documentation of all the other immunological abnormalities in this disease. ${ }^{1}$

The specific agent to which the immune cells in the muscle lesions are responding, whether auto- or neoantigen, in the context of either HLA Class I or II determinants, is still unidentified but we support the view that the damage in polymyositis is due to a combination of the effects of activated $\mathrm{T}$ cells, macrophages and B cells, with the first two playing the major roles.

This work was supported by the Muscular Dystrophy Group of Great Britain. Our grateful thanks are due to Dr HS Micklem of the Zoology Department, Edinburgh University and the Cancer Research Campaign for use of the Fluorescence Activated Cell Sorter, to Mrs Catherine Menzies for excellent technical assistance and to Dr David Doyle, for muscle biopsy material.

\section{References}

1 Behan WMH, Behan PO. Immunological abnormalities in polymyositis. Springer Semin Immunopathol 1985;8:267-93.

2 Behan WMH, Behan PO. Disturbance of regulatory lymphocyte subsets in polymyositis. Ann Neurol 1984;15:112-4.

3 Hauser SL, Reinherz EL, Hoban CJ, Schlossman SF, Weiner HL. Immunoregulatory $\mathrm{T}$ cells and lymphocytotoxic antibodies in active multiple sclerosis-weekly analysis over a six month period. Ann Neurol 1983;13:418-25.

4 Giorno R, Barden MI, Kohler PK, Ringel SP. Immunohistochemical characterization of the mononuclear cells infiltrating muscle of patients with inflammatory and noninflammatory myopathies. Clin Immunol Immunopathol 1984;30:405-12.

5 Rowe D, Isenberg DA, Beverley PCL. Monoclonal antibodies to human leucocyte antigens in polymyositis and muscular dystrophy. Clin Exp Immunol 1983;54:327-36.

6 Arahata K, Engel AG. Monoclonal antibody analysis of mononuclear cells in myopathies. I Quantitation of subsets according to diagnosis and sites of accumulation and demonstration and counts of muscle fibres invaded by T cells. Ann Neurol 1984;16:193-208.

7 Engel AG, Arahata K. Monoclonal antibody analysis of monoculear cells in myopathies. II Phenotypes of autoinvasive cells in polymyositis and inclusion body myositis. Ann Neurol 1984;16:209-15.

8 Lemoine NR, Ryan JF, Cox EL, Mayston V, Revell PA, Swash $M$. Immunohistochemical analysis of mononuclear cell subsets in inflammatory and non-inflammatory myopathies. $J$ Clin Pathol 1986;39:271-4.

9 Arahata K, Engel AG. Monoclonal antibody analysis of mononuclear cells in myopathies. III Immunoelectron microscopy aspects of cell-mediated muscle fibre injury. Ann Neurol 1986;19:112-25.

10 Bohan A, Peter JB. Polymyositis and dermatomyositis Parts I and II. $N$ Engl J Med 1975;291:344-7, 292:403-7. 
11 Abdulaziz Z, Gatter KC, Mason DY, Nash JRC, Stein H. An immunohistological study of the cellular constituents of Hodgkin's disease using a monoclonal antibody panel. Histopathology 1984;8:1-25.

12 Reinherz EL, Kung PC, Goldstein G, Schlossman SF. A monoclonal antibody with selective reactivity with functionally mature human T cells. J Immunol 1979;123:1312-7.

13 Ledbetter JA, Rouse RV, Micklem HS, Herzenberg LA. T cell subsets defined by expression of Lyt-1, 2, 3 and Thy-1 antigens. J Exp Med 1980;152:180-95.

14 Richie AWS, Gray RA, Micklem HS. Right angle light scatter: a necessary parameter in flow cytofluorimetric analysis of human peripheral blood mononuclear cells. J Immunol Methods 1983;64:109-17.

15 Greene WC, Fleischer TA, Waldman TA. Soluble suppressor cell supernatants eleborated by concanavalin-A. J Immunol 1981;126:1885-991.

16 Pauly JL, Sokal JE, Han T. Whole blood culture technique for functional studies of lymphocyte reactivity to mitogens, antigens or homologous lymphocytes. J Clin Med 1973;82:500-12.

17 Bresnan MJ, Bhan A, Borel Y, Hauser SL, Reinherz E, Weiner HL. Characterisation of T-cell subsets in peripheral blood and muscle in childhood dermatomyositis. Ann Neurol 1981;10:283.

18 Prineas JW. Pathology of the Guillain-Barré syndrome. Ann Neurol 1981;8 (Suppl 1):6-19.

19 Appleyard ST, Dubowitz V, Dunn MJ, Rose ML. Increased expression of HLA ABC Class I antigens by muscle fibres in Duchenne muscular dystrophy, inflammatory myopathy, and other neuromuscular disorders. Lancet 1985;i:361-3.

20 Isenberg DA, Rowe D, Beverley PCL. HLA antigen expression in myositis. Lancet 1985;i:703.

21 Behan WMH, Behan PO, Durward WF, Micklem HS. Lymphocyte subset abnormalities in polymyositis. $\mathrm{Br}$ Med $J$ 1983;287:181.

22 Lisak RP, Guerrero F, Skolnik P, Zweiman B. Circulating T-cell subsets in inflammatory myopathies. Neurology 1984;34 (suppl 1): 191 .

23 Iyer V, Fenichel GM, Lawton AR. T cell subsets in polymyositis. Ann Neurol 1983;13:452-3.

24 Levi F, Canon C, Blum J-P, Reinberg A, Mathe G. Large amplitude circadian rhythm in helper-suppressor ratio of peripheral blood lymphocytes. Lancet 1983;ii:462-3.

25 Nagel JE, Chrest FJ, Adler WH. Enumeration of T lymphocyte subsets by monoclonal antibodies in young and aged humans. $J$ Immunol 1981;127:2086-8.

26 Baker GHB, Iraani MS, Byron NA, et al. Stress, cortisol concentrations, and lymphocyte subpopulations. Br Med $J$ 1985;290:1393.

27 Dimitriu A, Fauci AS. Differential sensitivity of human lymphocyte subpopulations to azathioprine. Transplant Proc 1979;11:878-81. 